\title{
Role of Chinese government and Public-Private Partnership in combating COVID-19 in China
}

\author{
Hafiz Syed Mohsin Abbas ${ }^{1}$ D $\cdot$ Xiaodong $\mathrm{Xu}^{2} \cdot$ Chunxia Sun $^{2} \cdot$ Samreen Gillani $^{3}$. \\ Muhammad Ahsan Ali Raza ${ }^{4}$
}

Accepted: 29 June 2021

(c) The Author(s), under exclusive licence to Springer Science+Business Media, LLC, part of Springer Nature 2021

\begin{abstract}
COVID-19 has been called a Global Health Emergency worldwide. According to their available resources, developed and developing countries' public and private sectors are fighting against this pandemic. This paper examines how effective the Public-Private Partnership (PPP) strategies under the Chinese government response to control this COVID-19. The study takes the Chinese government and private sector's collective efforts for analysis and discussion from January 01 to October 31, 2020. Applying linear regression revealed that public governance strategies have worked to control this pandemic's severity and frequency. The results also show that despite the negative COVID-19 graph, the Chinese government has remained consistent in health and stringency measures. Furthermore, in cooperation with private sectors, China's emergency management has built two makeshift hospitals in 12 days and 5G technology implementation; Health Code application and volunteer works illustrate sharing governance by PPP. The study advises that by keeping in mind the strategy of PPP in China, other countries should also involve private sectors to mitigate emergency issues like COVID-19 for fast and effective outcomes and ask for assistance from the Chinese government and follow their quarantine and prudent policies to control this contagious disease. It further suggests that governments should engage private sectors before draft effective emergency preparedness policies to fight against future calamities.
\end{abstract}

Keywords COVID-19 pandemic · Public-Private Partnership/Collaboration (PPP) . Chinese government $\cdot$ Emergency preparedness $\cdot$ Linear regression

Hafiz Syed Mohsin Abbas abbas_hsm@hust.edu.cn

Extended author information available on the last page of the article 


\section{Introduction}

"Health is like money; we never have a true idea of its value until we lose it." The world has been facing many natural epidemics or outbreaks in the past, which had global health concerns, e.g., SARS virus in 2003, Bird Flu Virus in 2008 \& 2020, Ebola 2010, Dengue 2011, Tuberculosis and many others. Every nation maintains and develops its unique mechanism to stay healthy and fit according to its atmospheres and available food and work resources. These epidemics and viruses have trolled many health problems at an acute level, even to death. Due to these outbreaks, many commercial and industrial activities shut down, and governments have spent substantial public funding to prevent and cure these epidemics. Not only economic but psychological well-being has also been affected by these epidemics (Taylor et al., 2008). Healthcare is an important sector that needs extraordinary attention from government and private investors to provide adequate health services to common people. A recent epidemic/outbreak of Corona Virus or COVID-19 is the latest infection of viruses in Wuhan. ${ }^{1}$ As the world's most enormous population, it is not easy to tackle and ensure health services to each man; however, the Chinese government is trying to provide its best during this pandemic.

Global health condition has been poorly affected after the first case was reported on December, 31st 2019, in Wuhan. However, from this outbreak, a daily situation report has been issued since January 21, 2020, in global consciousness, which can assess its severity; at least one new country gets infected daily. Over 220 countries have now confirmed cases of COVID-19. China has been declared a Global Health Emergency by the World Health Organization (WHO) at the end of January 2020. After the declaration of a Global High-Risk situation by WHO, Assessments have made more than 45,632,406 cases worldwide, where around less than $1 \%$ of patients are in China until the end of October 2020 (Abbas et al., 2021a; Hale et al., 2020). As to Chines officials, treatments and proper vaccines of COVID-19 are still under development, but the Chinese government, Health staff, and other responsible institutes play their role to slow down this epidemic situation (Cohen \& Kupferschmidt, 2020). Furthermore, this outbreak rigorously affects the overall Chinese economy because several countries have suspended airline traffic, trade, the civilian movement to China, and even China. It is evidenced that health and socioeconomic factors are also affected by such conditions (Abbas et al., 2021a, 2021b, 2021c; Smith et al., 2019).

The Chinese government has taken steps to overcome this pandemic by utilizing its public and private institutions at the fastest level. However, according to updated figures, this epidemic shows a promising downward trend in China and upward in the rest of the world, especially in USA, India, and European countries. As per the World Bank, the government has a governance policy, and the private sector has the financial ability; the promising partnership guarantees the required outcome in dealing with social issues (World Bank, 2019). In the current situation, private sector

\footnotetext{
${ }^{1}$ The capital city of Central China and Hubei Province, which is considered an epidemic center of the COVID-19.
} 
involvement and the Chinese government significantly support the fastest access to public services. Despite governments' role and immediate strategies, the private sector has stood with the public sector side by side in this epidemic/outbreak worldwide, especially in China. Larger scale investors/industries or community individuals play their roles in this situation (Ung, 2020). The COVID-19 is rather severe than previous likewise epidemics, which demands more aggressive PPP efforts to control and eradicate such problems and, at the same time, efforts need to aware the public to use all necessary precautions measures. Although it is not untrue to say that the public sector bears more risks in public-private partnerships than the private sector, the rest are being equally shared \& safeguarded by the private sector (Zhang et al., 2020).

Moreover, as suggested by the studies, the public sector does not bear the risk alone in pandemic and disastrous natural situations. A responsible and supportive collaboration from the private sector is needed as a joint effort (Abbas et al., 2021a; Zhang et al., 2020). China's President Xi Jiping stated and admired the private business sector collaboration during a pandemic by lifting the socioeconomic burden of the Chinese government by offering temporary jobs, food, and medical accessories crisis and appeal to continuous that incoming spirit waves of COVID-19 like pandemic (The State Council of China, 2020).

How effective can the Public-Private Partnership (PPP) strategies under the Chinese government respond to control this COVID-19? Based on the discussion mentioned earlier and the scenario, this study examined a research question mentioned earlier that needs to be explored in the following sections of the paper. So, in support of Public-Private Partnership as a useful tool of the Chinese government and their efforts categorically, this present study makes a novel contribution for PPP supportive role and its impacts on controlling COVID-19 in China through empirical estimation with updated data and response indices of stringency and health policies of China in which previous studies are lacking (Abbas et al., 2021b; Ashraf, 2020; Hale et al., 2020). This study will also contribute to policy management and enrich the latest literature on coronavirus with PPP control measures and awareness by considering this constraint.

\section{Role of Public-Private Partnership and COVID-19 in China}

An increasing trend in each quarter of investment in China results from a growing population \& transportation requirements from the past. Nevertheless, the willingness of Public \& Private in the form of PPP to increase their respective share in investments is a thorough explanation of PPP's successful partnership. Being the 2nd largest country in terms of Area \& population, China needs a well-developed transport system and well-established infrastructure, especially in the health sector, which could not be fulfilled by the public sector alone. ${ }^{2}$ In this regard, until February

\footnotetext{
2 Appendix 1 mentioned the PPP investment amounts in RMB from 2016 to 2019 (latest available data). Also explained which sectors are the most critical sectors for the country's development.
} 
07, 2020, more than 3000 Chinese private companies incorporated this joint effort to produce masks and other PPE's for required instruments and accessories. The government also helped private sectors by announcing subsidies. According to the Chinese Planning Commission's latest statistics, CHINA's daily mask production reached 116 million in March 2020, which is 12 times higher than in February 2020 (Wang, 2020). Private companies in Shanghai are also producing reusable masks at affordable prices to support this epidemic (Yan, 2020).

COVID-19 pandemic has been controlled in China with phenomenal combined efforts of the Chinese government and business sector/private sector. This partnership can review many other industries such as Industrial Internet, 5G, ACE effect, Co-Governance, and sharing employment. World Economic Forum, 2020 stated that this disastrous situation was controlled due to both sectors' joint efforts. Soon after the lockdown was declared on January 24, 2020, the Chinese government announced to build two makeshift hospitals in 12 days on a war footing basis with the public, private investors with 2600 beds in Wuhan (an epidemic Centre of this COVID-19). Meanwhile, for the first time, Tencent Company used industrial 5G technology \& created an online artificial intelligence partnership. All relevant experts worked as a team online and completed planning for each hospital facet in this partnership. The hospital design plan was eventually completed in $24 \mathrm{~h}$ and the construction design in $60 \mathrm{~h}$ by employing BIM (Building Information Modeling) technology and private technology firms' insertion. During the initial phases of collaboration, below mentioned organizations provided their architectural services (communications, infrastructure, technology, funding) for hospital building and facilitation centers or shelters houses: Shenzhen One Foundation Charity Foundation, Ed Foundation, Nandu Foundation, China Merchants Charity Foundation, Zhengrong Charity Foundation, China Social Welfare Foundation, Beijing Pinglan Charity Foundation, China Poverty Alleviation Foundation, Beijing Normal University Governance Innovation Research Center, and International Council of Voluntary Agencies (ICVA) (CNCDRR, 2020). ${ }^{3}$

This collaboration added an ACE effect by sharing government stresses. By February 08 , WeChat introduced more than 100 mini-program services to communicate with the public and conference links for health consultations (Hubei Provincial People's Government, 2020a). DXY technology introduced remote medical services by employing artificial intelligence and provided real-time updates of the COVID19 pandemic. Along with this, live consultation to the public by the experts/doctors with ultra-high resolution image quality linked it with the central government in Beijing and introduced "Health QR Code" for the health status information. Alibaba, Tencent, Huawei, Byte Dance, and Baidu offer to surge online demands and provide human resource management. Moreover, food chains and restaurants have served delivery services to the public at their doorsteps; industries made delivery robots for the services (Xinhua, 2020). These supports emerged as a co-governance model for the modern society concept (Sengyee, 2020).

\footnotetext{
3 Appendix 2 denotes notable organizational and private investors' supports to the Chinese government on tacking COVID-19 Pandemic in China.
} 
PPP made a great effort by creating a very productive cartel to resolve socioeconomic issues such as food supplies and unemployment as city operations shut down after lockdown. To cope up with those problems, a new concept of "Sharing" has been introduced. $45 \%$ of all companies in China stepped up and hired temporarily unemployed staff during this lockdown economic crisis. According to estimation, around $92 \%$ of recruiting was made during this period under the concept of "sharing." This concept helped generate funds for unemployed people to maintain their livings and controlled the overall country's unemployment rate under this pandemic (CBI, 2020).

Similarly, companies like Alibaba and other big companies built Fund pools to support the medical staff and the government to fight against COVID-19 (Fang, 2020). The shining Tan's story stated that since February 9, 2020, Alipay (Alibaba Group) and WeChat both launched Health Code systems in their headquarters. As per Statistics, more than 6 Billion times, this health code app has been used in China with 900 Million in WeChat (Tencent Company).

Tan (2020), in Trustee chair of Chinese Business and Economics and Ankel (2020) in Business Insider, categorically stated Health Code Application policy enforcement joint efforts of government and Private Sectors in combating through and post COVID-19 impacts on China. Alibaba and Tencent initially put forward this plan; however, the later government added them to make a safety plan across the country. This App helps trace the public's health conditions, and its color scheme made it possible to detect the COVID-19 infected cases. Wu et al. (2020) stated that by access the location and user information, it turns into Green (Healthy and Free to travel), Yellow (7 days quarantined with mild symptoms), and Red (14-day quarantined with high symptoms). Smith (2020) in Financial Review also analyzed that this biotech initiative helps the government access the COVID-19 cases and control the transmission with on-time medical assistance.

Moreover, Walmart also donated 3 Million Yuan for the retail services and communities' services in Wuhan to cope with this pandemic (Hubei Provincial People's Government, 2020b). A recent White Paper issued by the State Council of Government of China dated June 07, 2020, made a significant contribution to PPP gratitude (The State Council of China, 2020). It categorically appreciated the public institutions' efforts, Military medical support, and aggressively supportive attitude of the private sector and the general public's volunteer services in fighting against the COVID-19 pandemic in China. Chinese Private Sector also offered its medical and financial assistance to developing countries, which is an excellent initiative in this crisis. In this scenario, Chinese Business tycoon Alibaba delivered various medical supplies in African and poor Asian countries and donated a handsome fund to developing the COVID-19 vaccine to medical teams in China and funded to international Research teams organized by World Health Organization.

Undoubtedly, this COVID-19 pandemic exerted tremendous management pressure on the Chinese government in artificial intelligence, human resources, Big data, medical accessories, food supplies, communications, education losses, and economic losses. However, the private cartels' on-time supports played a catalyst to release this pressure with equal support of funds, technology, consultation, human resources, and controlled socioeconomic pressure by employing co-governance 
and sharing concepts (Abbas et al., 2021a; World Economic Forum, 2020). Leading economic and data providing agencies World Economic Forum, Bloomberg, and The Thomson Reuters praised the Chinese Collaborations and was also commended by The President of China Xi Jinping during his visit to Wuhan dated March 10, 2020 (Bloomberg, 2020; Hubei Provincial People's Government, 2020c; Woo et al., 2020).

\section{Literature review}

A very few pieces of literature on current conjecture are available yet, as this is COVID-19; however, researchers have been actively focused for the past ten months and have been studying its symptoms, diagnosis, precautions, and treatments. Public-Private Partnership is not a new concept. It has been beneficial to the public at large. Along with Public-Private Partnership (PPP), Public to Public or Government to Government Partnerships is also an excellent approach to provide superior health services, especially in developing countries (Crisp, 2008).

Public-Private Partnership (PPP) elaborates as cooperation between the public and private sectors for the durable public services in which risk, cost, and values are shared (Burke \& Demirag, 2017). Most studies have focused on public collaborations in private matters to benefit (Boyer et al., 2016). However, merely a handful of research focuses on Private Collaboration in state or public services delivery matters (Bennett, 1998), resulting in a good collaboration pattern (Gold et al., 2012) to deal with open issues. General public involvement in PPP does substantial effects (Bingham, 2008) on governance matters (Nabatchi, 2010). Although in policy framing, the main component is government; however, the general public and private sectors act as a catalyst to achieve these objectives (Pirkis et al., 2004; Thadani, 2014).

In short, PPP plays a significant part in engrossing the private sector to enhance the government sector capacity and coverage of the health sector, primarily (Schmidt \& Dmytryk, 2014; Wong et al., 2015) and trustfulness to provide service outcomes (Asquith et al., 2015). It concluded that good public health triggers the other sectors' development as healthy economic activities (Medhekar, 2014). PPP reduces the financial pressure to provide public health services to the general public in emergencies and increases state efficacy (Ferreira \& Marques, 2020; Givens \& Busch, 2013; Santandrea et al., 2016). PPP also contributes as a valuable tool towards sustainability to public services (Xiong et al., 2019). Because Public and Private Sectors cannot bear risks and exposure associated with partnerships for public service delivery to the masses alone (Lam \& Yang, 2020; Liu \& Xue, 2019). PPP is an innovative way of inter-sector collaboration in management and resource allocation for better public services (Chung \& Hensher, 2018; Maraña et al., 2020). As per the recent European Commission statement on February 25, 2020, a significant PPP (Public 45 Million Euro and 90 Million Euro) and investment plans announced making a vaccine to deal with COVID-19 (Zubașcu, 2020).

An extraordinary PPP control measure has been observed in SARS-2003, which hit China severely (James et al., 2006). Public and private health agencies collaborate in different parts of the world to mitigate the effects and control problems such 


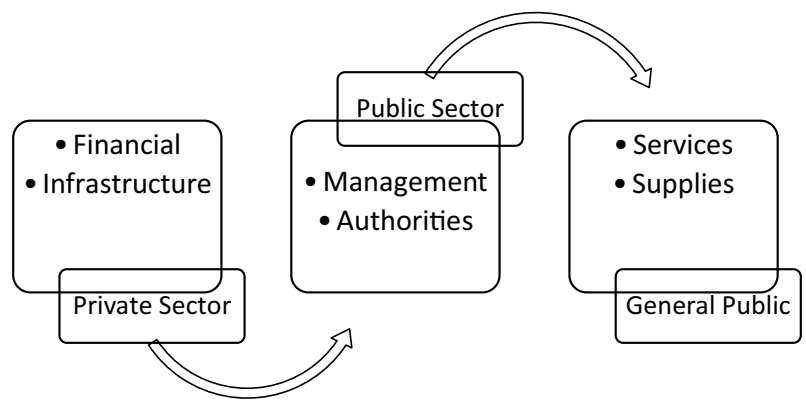

Fig. 1 Old conceptualized framework of PPP for Public Service. Source: The World Bank

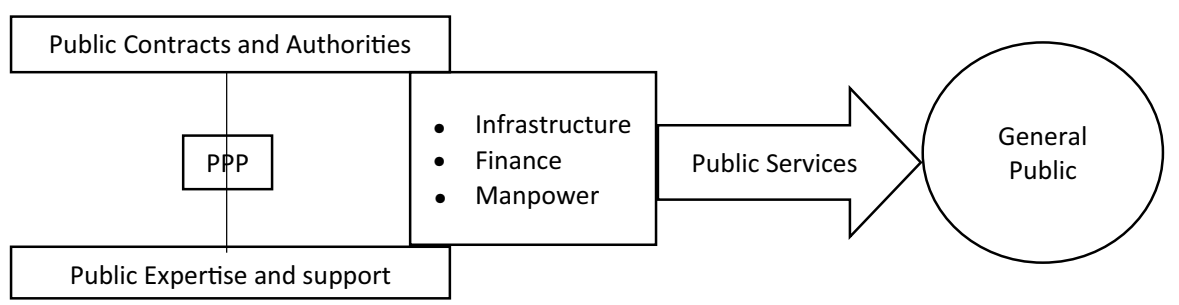

Fig. 2 New conceptualized framework for PPP for Public Services, Authors estimation

as HIV/AIDS and Tuberculosis to get desired objectives (Brunne, 2009; Sinanovic \& Kumaranayake, 2010). It is evidenced that PPP has played a crucial role in developing cures and treatment at a large scale in epidemic situations, especially in developing countries (Auzzir et al., 2014; Odevall et al., 2018; Zumla et al., 2015). Along with the development of a cure, PPP has strategic significance to prepare for emergency problems in advance, especially in new cases, as more and more expertise and funds need to allocate in such situations (Aruru et al., 2020; Peeling et al., 2019).

International agencies and domestic PPP have tried to develop the vaccines and, at the same time, put in motion precautionary measures in epidemic situations, which have been advantageous to control epidemic situations and benefit the public at large (Pagliusi et al., 2019). Developing countries have benefited from this PPP collaboration by providing reasonable incentives and planning to private inducers (Comendeiro-Maaløe et al., 2019; Shibu et al., 2020). PPP needs for vaccine development; in fact, it requires health facilities, daily medicines, and precaution measures to reduce services burden on the public sector (Abbas et al., 2020, 2021a, b; Aruru et al., 2020; Ferreira \& Marques, 2020).

\subsection{Conceptualized frameworks of PPPs (old and new)}

According to the World Bank, developed and developing countries follow this conceptual framework in public services. The new approach focuses on service delivery and infrastructure and financing support to public authorities, especially in outbreak/ 
epidemic situations. Figure 1 shows the traditional framework of Public-Private Partnerships. The private sector is a facilitator in finance, infrastructure, and human resources to public service delivery institutions because public institutions are solely responsible and deliver services to the public.

On the other hand, Fig. 2 depict an updated version of the Public-Private Partnership observed in China during this COVID-19 pandemic. An appropriate and ontime private contribution in all aspects with the public sector made it possible to overcome this disastrous situation. Based on the above literature and old and new concepts of PPP, the study has computed our research framework, explaining the new approach to building PPP in public services to provide services to the masses. As per this conceptualization model, the Private sector, not only a facilitator of public services, stood side-by-side with the Chinese government (Xiao \& Lam, 2019). Both sectoral (Public and Private) collaborations develop and provide the best possible services to the public, and due to this contribution, the private sector gets subsidies for research and development (Comendeiro-Maaløe et al., 2019). In this particular case, the Chinese health, IT, education, and community sectors in Wuhan City and the rest of China during the COVID-19 Pandemic situation showed tremendous support to the government and provided the best possible public services (Xiang et al., 2020).

\section{Methodology}

This study has analyzed the Chinese government's response to controlling China's COVID-19 situation through stringency policies and health containment indices. Furthermore, public and private partnership or collaboration as a supportive role in China has been discussed as a critical strategy to combating COVID-19. The study used the Oxford University dataset of New Confirmed Cases (NCC), Death and Government response Indices (Stringency Response Index-SRI and Health Containment Index-HCI) of COVID-19from January 01 to October 31, 2020 (Abbas et al., 2021a, b; Hale et al., 2020). Moreover, the study has analyzed its collective data through descriptive, graphical, and empirical tools to achieve its objective.

Due to the unavailability of any periodic statistics of Public-Private Partnership in China in recent times, we have to rely on the collective efforts and supports of Chinese government and business sectors efforts issued by the State news agencies, world-leading databases forums, and Chinese authorities press releases to investigate the situation and the impacts of their efforts on controlling the COVID-19. For Empirical analysis, this study applied Pearson's correlation and linear regression by using STATA version 18 (Abbas et al., 2021a, 2021b, 2021c; Bartlett et al., 2020; Hazra \& Gogtay, 2016; Karmalkar et al., 2019). Linear regression is a reasonable estimation when the study examines the relationship between one or two explanatory variables and the dependent variable in a simplified way. Simultaneously, the Dickey-Fuller unit root testing was performed for data reliability and accuracy 


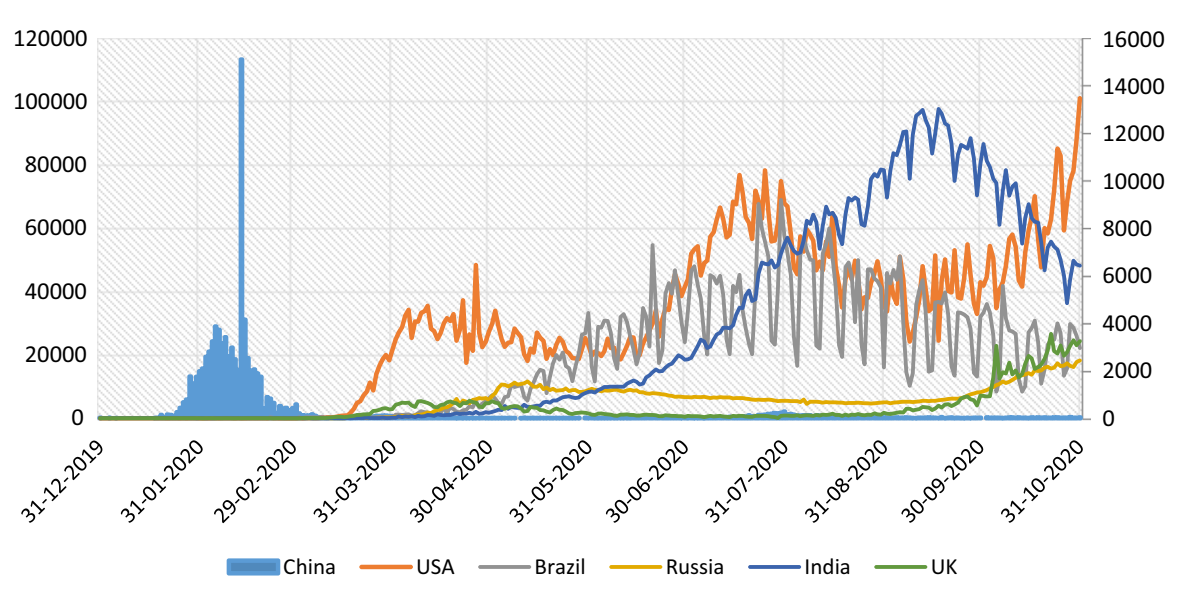

Fig. 3 COVID-19 new confirmed cases. Source: Authors Estimation

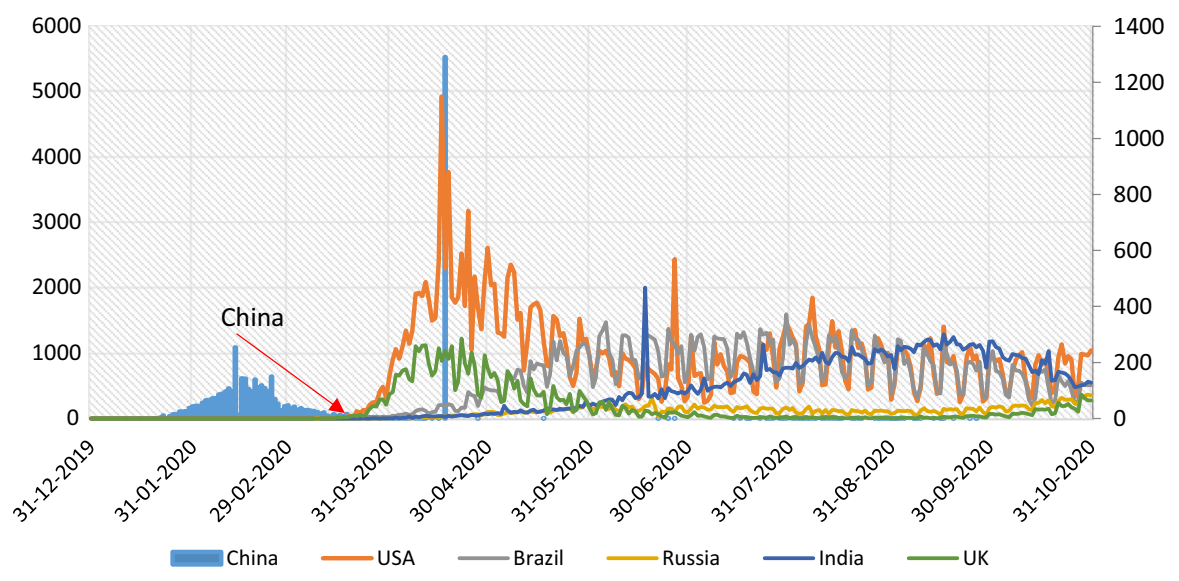

Fig. 4 COVID-19 death cases worldwide Authors Estimation

(Ferreira, 2016; Paparoditis \& Politis, 2018; Ramenah et al., 2018) ${ }^{4}$. Following is the estimated equation;

$$
N C C=\partial+\beta 1(S R I)+\beta 2(H C I)
$$

$\mathrm{NCC}=$ New Confirmed Cases, SRI $=$ Stringency Response Index, HCI $=$ Health Containment Index, $\partial=$ Constant $\beta=$ Slope of the intercept.

\footnotetext{
${ }^{4}$ See Appendices 3 and 4.
} 
Table 1 Descriptive statistics. Source: Authors estimation

Table 2 Pairwise correlation. Source: Authors estimation

\begin{tabular}{llllll}
\hline Variable & Obs. & Mean & Std. Dev. & Min & Max \\
\hline DAYS & 303 & 152 & 87.61278 & 1 & 303 \\
SRI & 303 & 68.35835 & 20.06709 & 0 & 81.94 \\
HCI & 303 & 70.87162 & 17.10535 & 7.99 & 85.42 \\
\hline
\end{tabular}

\begin{tabular}{llll}
\hline Variables & SRI & HCI & NCC \\
\hline SRI & 1.0000 & & \\
HCI & 0.9944 & 1.0000 & \\
NCC & 0.0904 & 0.0414 & 1.0000 \\
\hline
\end{tabular}

\section{Results and data analysis}

\subsection{Graphical analysis}

Figures 3 and 4 show the daily situation of confirmed new infected cases and death cases in China compared to other the most affected countries as of June 17, 2020, of the COVID-19 situation. It is evidenced in Fig. 3 that during the early stages of a pandemic, affected cases in China kept increasing. At the same time, the rest of the world showed a minor upward trend up until day 28 or week 4 (On day 28, as of February 17, 2020, 17,410 confirmed laboratory cases were identified before most of the patients were clinically confirmed, which was suspected before this period). Initially, the Chinese government tried to safeguard the people from affected places and dealt with international citizens' evacuation. However, after week four, the Chinese government fought back with efficient strategy and prevention plans to deal with this problem, and results are depicted in the above figure prominently. This rehabilitation situation has been occurring due to the excellent PPP strategy. With the private sector's support added with the public's tremendous backing, public governance made it possible for China to overcome this problem.

Figure 4 illustrates the updated fatality situation in China and the rest of the world. However, until week three of the COVID-19, in comparison to China, the situation in the rest of the world shows a substantial incremental rate in worldwide fatality cases (except China) from week four to date; however, the pace of new topics is slowing down but still cumulative effect at increasing side. An interesting fact is that initially, the world has felt pity for China due to this epidemic and a curse on their eating habits. However, COVID-19 has already spread to the whole world due to the world's strongest economies' carelessness and weak response system; they started to blame China for this calamity. Furthermore, being a rival of China, they do not appreciate the Chinese government's sacrifices and efforts and its people. Moreover, it revealed that to date, 1,189,174 lives have already gone. 
Table 3 Linear regression analysis. Source: Authors estimation

\begin{tabular}{|c|c|c|c|c|c|c|}
\hline Source & SS & $\mathrm{DF}$ & \multicolumn{2}{|l|}{ MS } & Number of Obs. & 303 \\
\hline & & & & & $\mathrm{F}(2,300)$ & 41.54 \\
\hline Model & 79033991.6 & 2 & \multicolumn{2}{|c|}{39516995.8} & Prob. $>$ & 0 \\
\hline Residual & 285408016 & 300 & \multicolumn{2}{|c|}{951360.052} & R-squared & 0.2169 \\
\hline & & & & & Adj. R-squared & 0.2116 \\
\hline Total & 364442007 & 302 & \multicolumn{2}{|c|}{1206761.61} & Root MSE & 975.38 \\
\hline $\mathrm{NCC}$ & Coeff. & Std. Err. & $\mathrm{t}$ & $\mathrm{P}>|\mathrm{t}|$ & [95\% Conf. & Interval] \\
\hline SRI & 239.2479 & 26.35335 & 9.08 & 0.000 & 187.3871 & 291.1088 \\
\hline $\mathrm{HCI}$ & -276.4297 & 30.91636 & -8.94 & 0.000 & -337.2701 & -215.589 \\
\hline Constant & 3537.554 & 446.6897 & 7.92 & 0.000 & 2658.512 & 4416.596 \\
\hline
\end{tabular}

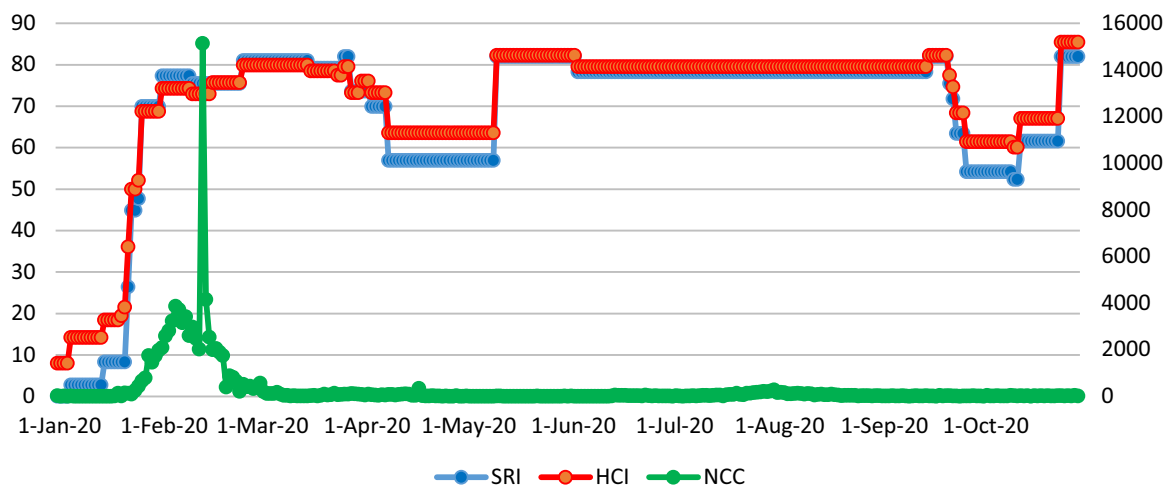

Fig. 5 Chinese government response and COVID-19 situation. Source: Hale et al. (2020) and DXY (2020)

\subsection{Descriptive \& empirical analysis}

Table 1 described the descriptive statistics of the selected variables and period.

The results of Pearson's correlation are explained in Table 2. Health Containment policies and corrective measures positively correlated with COVID-19 decreasing numbers. On the other hand, Stringency policies in China by closing schools, institutions, offices, and other public places have contributed to combating COVID-19 and reducing the numbers with the strict, consistent lockdown.

Table 3 explained the linear regression analysis. Before applied linear regression, the study tested the study sample with the Dickey-Fuller unit root test for accuracy and reliability of the data; all the study variables individually have $\mathrm{z}(\mathrm{t})$ value greater than critical value $1 \%$ (see Appendices 3, 4). In complete linear regression analysis, both SRI and HCI have a 95\% confidence interval to NCC. Moreover, the study has a $0.2160 \mathrm{R}$-square value that depicted Chinese policy measures affecting since the pandemic. 
In summed up, Fig. 5 demonstrates the Chinese government's responses to fighting against COVID-19. It shows that since January 2020 to date, Chinese policies have been remained consistent, even the situation has under control. It further portrays that in August 2020 to date, in preparation and during National Holiday in China, Chinese health and lockdown policies remained effective and stricter than previous months (June-July).

\section{Discussion}

In light of the above literature, data, and results, it is evidenced that the Chinese government and private sector collaboration played excellent collective efforts to mitigate/control this epidemic and have effectively tried to get complete control over this (Asquith et al., 2015). Public and business owners obeyed the Chinese government instructions and guidelines issued by the authorities. Its city lockdown and proper quarantine activities show their positive feedback, and as a result, COVID-19 severity and frequency are slowing down its pace in China (Abbas et al., 2021a, b; Xiang et al., 2020).

As managing the world's largest population and still being a developing country, the Chinese government, the private sector, and the general public collectively have played their role to eradicate or mitigate this outbreak's adverse effect. However, other developed countries are constantly striving to prevent this issue due to weak governance (Cohen \& Kupferschmidt, 2020). The same collaboration results have been evidenced by other scholars, which help to understand the comparative administration analysis (Crisp, 2008). PPP strategy helps achieve the best possible results to control epidemic misfortunes (Peeling et al., 2019). This same principle is exercised or observed in China in this COVID-19 situation.

Despite effective government policies, cooperative, private sector support is also needed to provide Public health services to the masses (Antonio \& Feng, 2017). The Chinese government has adopted this strategy, and the results are fruitful. The Chinese Health Commission's official statement on March 10, all facilitation centers or shelter houses in Wuhan (an epidemic Centre of COVID-19) for patients, was closed, and all patients were successfully recovered (National Health Commission China, 2020). Until October 31, 2020, more than 94\% confirmed cases have recovered in China, and $5.56 \%$ of deaths occurred. Rest was in mild symptoms and under observation, China's great success against this novel COVID-19 with mutual public and private sector support. However, the situation is getting worse in the rest of the world, with only $62.60 \%$ recovered cases and the death toll reaching more than $2 \%$ (see Appendix 2).

PPP is an excellent approach to combating COVID-19; it stimulates the services delivery to the masses and health services. Because by providing services, authorities should fulfill the other associated socioeconomic needs, e.g., food, shelter, education, and better living standards, to the public, and for that, PPP is a thorough approach in developing countries (Xue et al., 2020). Medhekar (2014) analyzed that new development and research will support and subsidize the government's private health sector. The same has been examined by other studies (Comendeiro-Maaløe 
et al., 2019). De Sousa et al. (2020) that the Public health sector should engage community psychological health practitioners to counsel the general public's mental health because COVID-19 impacted immense mental distress and uncertainty among the public. Furthermore, Bodrud-Doza et al. (2020) stated that developing countries need the public-private sectors to support combat and cope with the COVID-19's prevailing socioeconomic devastation. The government should invest and develop a strong epidemic or risk preparedness mechanism.

China has been facing huge financial, economic, and social losses due to this epidemic; however, it has shown that China is the real leader of the world market share by dealing with this biomedical war. Public authorities and private investors worked side by side in this critical situation. Along with them, the general public, teachers, and students have been working as volunteers and fully supported the government to control the situation, which is the best example of PPP in an epidemic situation. By considering their efforts, governments should develop efficient community health centers with adequate resources and appropriate training. WHO-China's joint mission also played a notable role in controlling this situation.

As per the latest statistics, European and East Asian states have been affected by this virus for the last four weeks, showing weak emergency management in novel epidemics. Chinese government emergency management also worked in this scenario, which played its role in dealing with $20 \%$ world's population in China and worldwide human well-being at their best due to epidemic situations (Taylor et al., 2008; Tol et al., 2020). However, Chinese and international scientists have been trying to discover the proper cure for this virus, which hopefully soon be successful. Chinese government shows much needed responsible attitude and measures to control this problem; two hospitals with $2,000+$ beds $^{5}$ were built in Wuhan on a war footing basis in 12 days are the best example of the Chinese government's efficient emergency management.

A few days ago, the countries that blamed China for this epidemic now requested China's assistance to deal with this Novel Virus, which clearly shows China's excellent governance strategy (Ashraf, 2020; Hale et al., 2020). European and American states must follow the Chinese precautionary guidelines and policies to deal with this issue and control this problem. China's victory strategies against COVID-19 with Health Code Application (Tan, 2020) have also been adopted in America and Australia to detect COVID-19 patients with the private sector's support, e.g., Apple and Google. At New York Simulation on March 09, 2020, it has asked for help from the Global Economic Forum (Brende \& Morhard, 2020). The WHO has been praising Chinese governance throughout this bio-medical war and offered support from time to time with human resources and experts assistance because, with physical health, mental health is also required by the PPP collaboration to control epidemic situations (Xiang et al., 2020). We hope that these efforts will make a powerful

\footnotetext{
5 Capital City of Hubei Province \& Central China) it is a city of 11 Million people and the epidemic Center of this Novel Corona Virus-2019. The Chinese government has arranged 40,000 beds in existing and newly built hospitals and established quarantine facilitation centers in Wuhan with 70,000 beds capacity for this epidemic.
} 


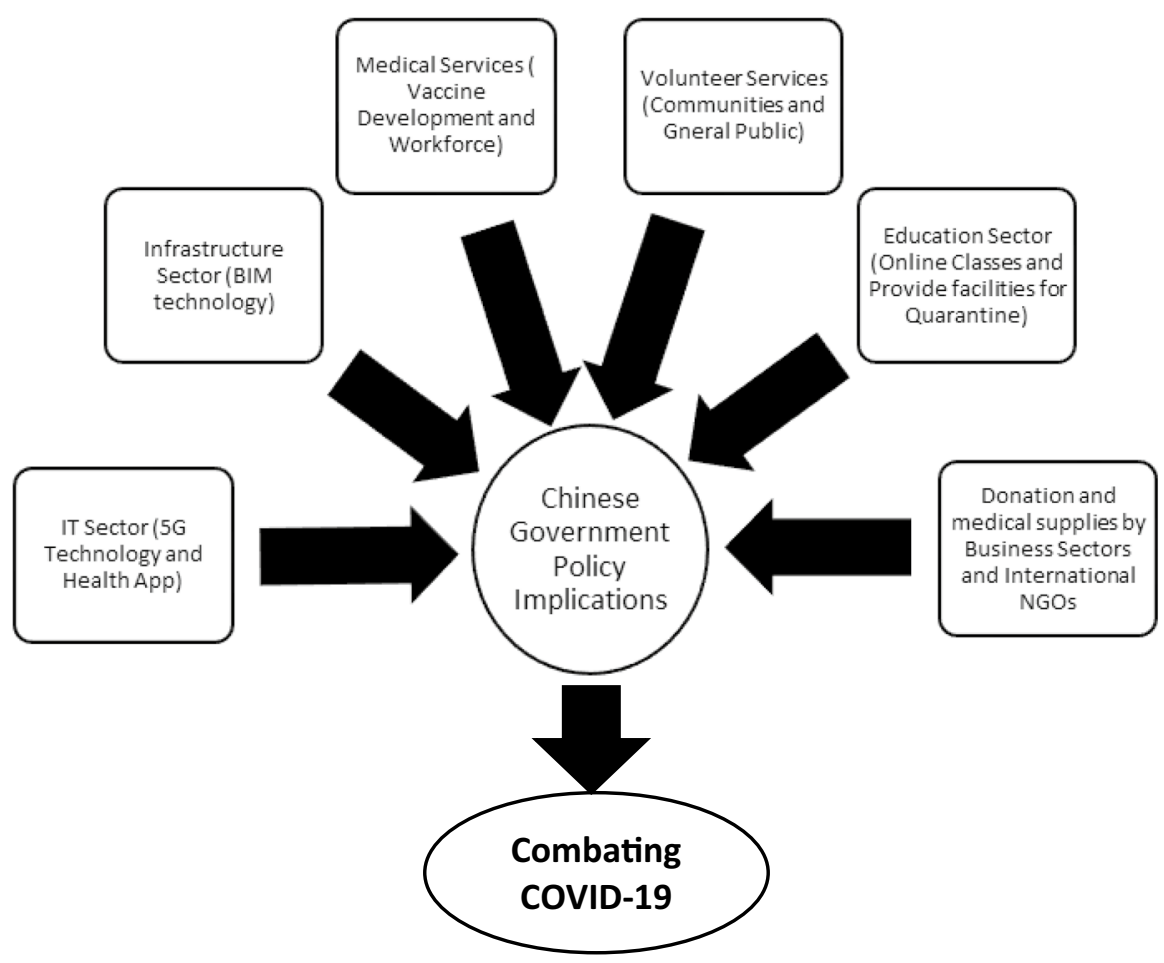

Fig. 6 Role of private sectors and government policy implications. Authors estimation

impact on combating the COVID-19 situation there, too, as in China. Unfortunately, we have not comprehended such collective private sectors support in the rest of the world other than China yet, which a sad reality is. However, sectoral support shall make a difference in combating the COVID-19 pandemic and future unforeseen casualties if properly working with respective governments and lift the socioeconomic burden, just like the Chinese PPP did demonstrate in Fig. 6.

\section{Conclusion and policy implications}

This study aimed to investigate the Public-Private Collaboration/Partnership as a supportive role in combating COVID-19 in China. Based on government officials' documents and electronic blogs, and the government response tracker of Stringency and Health containment index from Oxford University. Results depicted PPP and consistent lockdown and health control measures have remained a vital instrument in combating COVID-19 in situations throughout the period since January to date despite relaxation in lockdown policies.

In this outbreak, this triangle policy (the collaboration of the Public sector, Private sector, the general public) is the dire need of time. Although the Chinese government is well equipped and prepared to deal with likewise emergency issues but, 
because of a rapid increase in the worse consequences of COVID-19, these types of equipment seem not sufficient but require equal support from the private sector to put in motion as efficient and effective measures to control \& ultimately prevent the epidemic. The public sector alone cannot fulfill the increasing demand for masks, medical instruments, hospitals, and medicines to the public at large. Hence an equal or adequate backing from private sector industries is mandatory to tackle this alarming situation. Public-Private Partnership (PPP) is an important strategy to deal with emergencies and outbreaks, particularly in developing countries. Even though the private sector mainly focuses on the profitability of the firms rather than public services. Nevertheless, with proper government support in terms of subsidy, the industry becomes a vital ally on such matters.

Nevertheless, it further concludes that a consistent surveillance and watchdog role of the Beijing government and provincial governments of Hubei and other provinces played extraordinary administrative practices, which made an illustration of good governance. The role of PPP and the general public efforts helped the Chinese government control the situation much better than the rest of the world. The rest of the world's governments, especially the US and central European countries, should follow China's step-by-step stringency measures, helping them mitigate the adverse effects and control the situation. It will also play a critical role in rehabilitation in post-pandemic actions and develop a responsible attitude among public and private sectors in conjugation with the government in combating COVID-19 and future viruses or severe infections attacks if unfortunately happens.

This study has discussed and argued that private sectors (business units, private institutions, communities, and the general public) support public institutions or government during combating COVID-19 in China. Due to data unavailability, this study could not make much empirical analysis or statistical estimation and had to rely on the supportive and contributing efforts of private sectors from various blogs and official statements. Moreover, this study identified all kinds of business and private support, e.g., technology, medical, community, and human resources assistance to the public in combating COVID-19, making this piece of work comprehensive. For future study, if relevant data are available, a more profound analysis by focusing on a specific industry such as IT, medical, community, and volunteering services can be identified. Their categorically supportive role can be investigated in controlling COVID-19 in China and other states. Also, along with general public institutions, military services can be an excellent approach for future studies.

\section{Appendices}

Appendix 1 Chinese PPP projects contribution in RMB, Authors estimation. Source: Ministry of Finance, PR China 


\begin{tabular}{lll}
\hline PPP amount in billion RMB & & \\
\hline Year & Period & HealthCare \\
\hline 2016 & Q1 & N/A \\
2016 & Q2 & N/A \\
2016 & Q3 & N/A \\
2016 & Q4 & N/A \\
2017 & Q1 & 27.00 \\
2017 & Q2 & 36.70 \\
2017 & Q3 & N/A \\
2017 & Q4 & 44.70 \\
2018 & Q1 & 57.30 \\
2018 & Q2 & 65.60 \\
2018 & Q3 & 74.50 \\
2018 & Q4 & 89.00 \\
2019 & Q1 & 100.90 \\
2019 & Q2 & 106.60 \\
2019 & Q3 & 115.70 \\
\hline
\end{tabular}

*N/A donates Not Available date of the respective year

**RMB gives Renminbi (Yuan) Chinese Currency

Appendix 2 Notable private contributions to the Chinese government on tackling COVID-19 pandemic

\begin{tabular}{|c|c|c|c|}
\hline Donors & Amount & Activity & Source \\
\hline 231 Anonymous & 18,574 USD & Give Healthcare & Give Asia \\
\hline Walmart & 3 million Yuan & Retail Services & $\begin{array}{l}\text { Hubei Foreign Affairs } \\
\text { Office }\end{array}$ \\
\hline 150 Investment Groups & 2.5 Billion USD & Investment & Crunchbase \\
\hline 159 Investment Groups & 301,955 USD & Investment & Crunchbase \\
\hline KPCB XIX & 700 Million & Investment & Crunchbase \\
\hline JD & 6 Billion Yuan & $\begin{array}{l}\text { Investment and reha- } \\
\text { bilitation }\end{array}$ & $\begin{array}{l}\text { Hubei Foreign Affair } \\
\text { Office }\end{array}$ \\
\hline Alibaba & $\begin{array}{l}144 \text { Million USD, } \\
\text { 300,000 Free masks, } \\
\text { and Loans to 360,000 } \\
\text { shop owners }\end{array}$ & $\begin{array}{l}\text { Interest-Free Loan, } \\
\text { Rehabilitation, } \\
\text { Wuhan Relief Fund } \\
\text { and Aid for Medical } \\
\text { Teams }\end{array}$ & $\begin{array}{l}\text { Hubei Foreign Affair } \\
\text { Office, Axios }\end{array}$ \\
\hline $\begin{array}{l}\text { 69+Projects by Private } \\
\text { investors including } \\
\text { Alibaba, Huawei, } \\
\text { Tencent }\end{array}$ & $\begin{array}{l}\text { More than } 245 \text { Billion } \\
\text { Yuan }\end{array}$ & $\begin{array}{l}\text { Investment and Reha- } \\
\text { bilitation and Wuhan } \\
\text { Relief Funds }\end{array}$ & $\begin{array}{l}\text { Hubei Foreign Affair } \\
\text { Office }\end{array}$ \\
\hline Jack Ma & 5.8 Million USD & $\begin{array}{l}\text { Research \& develop- } \\
\text { ment for vaccine }\end{array}$ & Axios \\
\hline Bill Gates & 100 Million USD & $\begin{array}{l}\text { Research \& develop- } \\
\text { ment for vaccine }\end{array}$ & Axios \\
\hline Tencent & 42.7 Million USD & Wuhan Relief Funds & Axios \\
\hline
\end{tabular}




\begin{tabular}{|c|c|c|c|}
\hline Donors & Amount & Activity & Source \\
\hline Microsoft & 142.4 Million USD & Wuhan Relief Funds & Axios, Financial Times \\
\hline Boeing & 250,000 Free mask & Aid to Medical Staff & Axios \\
\hline $\begin{array}{l}\text { Fenghong Asset Man- } \\
\text { agement }\end{array}$ & 4.2 Million USD & Wuhan Relief Fund & Bloomberg \\
\hline $\begin{array}{l}\text { POSCO and Sungjoo } \\
\text { Foundation from } \\
\text { Korea }\end{array}$ & 5 Million USD & Wuhan Relief Fund & Reliefweb \\
\hline $\begin{array}{l}\text { Various International } \\
\text { NGOs }\end{array}$ & $\begin{array}{l}\text { 2.3 Million mask, } \\
\text { 11,000 Medical suits, } \\
\text { 310,000 Medical } \\
\text { gloves }\end{array}$ & $\begin{array}{l}\text { Under HOPE Project, } \\
\text { Aid to Medical Teams }\end{array}$ & Reliefweb by Devex.com \\
\hline American NGO & $\begin{array}{l}\text { 572,000 N95 Masks, } \\
\text { 272,000 Medical } \\
\text { gloves }\end{array}$ & $\begin{array}{l}\text { Aid to Medical teams } \\
\text { in China }\end{array}$ & $\begin{array}{l}\text { Direct Relief Organiza- } \\
\text { tion, devex.com }\end{array}$ \\
\hline Chinese Banks & 6 Trillion Yuan & $\begin{array}{l}\text { Payment against pre- } \\
\text { vention and control } \\
\text { epidemic situation }\end{array}$ & State Council of PR China \\
\hline $\begin{array}{l}\text { Communist party } \\
\text { members }\end{array}$ & 7.68 Billion Yuan & $\begin{array}{l}\text { Donated to COVID-19 } \\
\text { relief fund }\end{array}$ & State Council of PR China \\
\hline
\end{tabular}

Appendix 3 COVID-19 updated snapshot (authors estimation). Source: DX doctor real-time report-coronavirus live updates October 31,2020

\begin{tabular}{lllc}
\hline Region & Recovered $^{*}$ & Deaths & Under observation \\
\hline China & $94.26 \%$ & $5.16 \%$ & $0.58 \%$ \\
Rest of the world & $62.60 \%$ & $2.60 \%$ & $34.80 \%$ \\
\hline
\end{tabular}

*Its round-off figures, for exacts numbers Please visit the WHO website or (ncov.dxy.cn)

Appendix 4 Dickey-Fuller unit root testing. Source: Authors estimation

\begin{tabular}{|c|c|c|c|c|}
\hline \multicolumn{5}{|c|}{ Interpolated Dickey-Fuller } \\
\hline & Test statistics & $1 \%$ Critical value & $5 \%$ Critical value & $10 \%$ Critical value \\
\hline \multicolumn{5}{|c|}{ Dickey-Fuller test for unit root (SRI); Number of Obs. $=302$} \\
\hline \multirow[t]{2}{*}{$\mathrm{Z}(\mathrm{t})$} & -3.484 & -3.456 & -2.878 & -2.57 \\
\hline & MacKinnon ap & mate $\mathrm{p}$-value for $\mathrm{Z}(\mathrm{t}$ & 084 & \\
\hline \multicolumn{5}{|c|}{ Dickey-Fuller test for unit root (HCI); Number of Obs. $=302$} \\
\hline \multirow[t]{2}{*}{$\mathrm{Z}(\mathrm{t})$} & -3.908 & -3.456 & -2.878 & -2.57 \\
\hline & MacKinnon ap & mate $\mathrm{p}$-value for $\mathrm{Z}(\mathrm{t}$ & 020 & \\
\hline \multicolumn{5}{|c|}{ Dickey-Fuller test for unit root (NCC); Number of Obs. $=302$} \\
\hline \multirow[t]{2}{*}{$\mathrm{Z}(\mathrm{t})$} & -8.861 & -3.456 & -2.878 & -2.57 \\
\hline & MacKinnon ap & hate $\mathrm{p}$-value for $\mathrm{Z}$ & 000 & \\
\hline
\end{tabular}


Funding This research did not receive any grant from University, funding agencies in the public, commercial, or not-for-profit sectors.

\section{Declarations}

Conflict of interest The authors declare that they have NO known competing financial interests or personal relationships that could have appeared to influence the work reported in this paper.

\section{References}

Abbas, H. S. M., Gillani, S., Ullah, S., Raza, M. A. A., \& Ullah, A. (2020). Nexus Between Governance and Socioeconomic Factors on Public Service Fragility in Asian Economies. Social Science Quarterly, 101(5), 1850-1868.

Abbas, H. S. M., Xu, X., \& Sun, C. (2021a). China Health Technology and Stringency Containment measures during COVID-19 pandemic: A discussion of First and Second wave of COVID-19. Health and Technology. https://doi.org/10.1007/s12553-021-00519-9

Abbas, H. S. M., Xu, X., \& Sun, C. (2021b). COVID-19 pandemic, government response and policy implications in CIIP (China, India, Iran and Pakistan). Journal of Emergency Management. https:// doi.org/10.5055/jem.0529

Abbas, H. S. M., Xu, X., Sun, C., Ullah, A., Gillani, S., \& Raza, M. A. A. (2021c). Impact of COVID-19 pandemic on sustainability determinants: A global trend. Heliyon. https://doi.org/10.1016/j.heliyon. 2021.e05912

Ankel, S. (2020). As China lifts its coronavirus lockdowns, authorities are using a color-coded health system to dictate where citizens can go. Here's how it works. Retrieved from https://www.businessin sider.com/coronavirus-china-health-software-color-coded-how-it-works-2020-4

Antonio, N., \& Feng, C. (2017). Public-private partnerships in Chinese hospitals and knowledge transfer. In Organizational learning in Asia (pp. 153-169). Elsevier.

Aruru, M., Truong, H.-A., \& Clark, S. (2020). Pharmacy Emergency Preparedness and Response (PEPR): A proposed framework for expanding pharmacy professionals' roles and contributions to emergency preparedness and response during the COVID-19 pandemic and beyond. Research in Social \& Administrative Pharmacy: RSAP, 17(1), 1967-1977.

Ashraf, B. N. (2020). Socioeconomic conditions, government interventions and health outcomes during COVID-19. Covid Economics, 37, 141-162.

Asquith, A., Brunton, M., \& Robinson, D. (2015). Political influence on public-private partnerships in the public health sector in New Zealand. International Journal of Public Administration, 38(3), $179-188$.

Auzzir, Z. A., Haigh, R., \& Amaratunga, D. (2014). Public-private partnerships (PPP) in disaster management in developing countries: A conceptual framework. Procedia Economics and Finance, 18, 807-814.

Bartlett, P. L., Long, P. M., Lugosi, G., \& Tsigler, A. (2020). Benign overfitting in linear regression. Proceedings of the National Academy of Sciences, 117(48), 30063-30070.

Bennett, A. (1998). Sustainable public/private partnerships for public service delivery. Paper presented at the Natural Resources Forum.

Bingham, L.B. (2008). Lateral Thinking for Collaborative Public Management. In L. B. Bingham, R. O’Leary \& C. Carlson (Eds.), Big Ideas in Collaborative Public Management (1st Ed., pp. 3-16). Routledge.

Bloomberg. (2020). China to lift lockdown over virus epicenter Wuha. Retrieved from https://www.bloom berg.com/news/articles/2020-03-24/china-to-lift-lockdown-over-virus-epicenter-wuhan-on-april-8

Bodrud-Doza, M., Shammi, M., Bahlman, L., Islam, A. R. M., \& Rahman, M. (2020). Psycho-social and socioeconomic crisis in Bangladesh due to COVID-19 pandemic: A perception-based assessment. Frontiers in Public Health, 8, 341.

Boyer, E. J., Van Slyke, D. M., \& Rogers, J. D. (2016). An empirical examination of public involvement in public-private partnerships: Qualifying the benefits of public involvement in PPPs. Journal of Public Administration Research and Theory, 26(1), 45-61. 
Brende, B., \& Morhard, R. (2020). A New York simulation showed we weren't prepared for coronavirus. But it's not too late to act. The World Economic Forum COVID Action Platform. Retrieved from weform.org website: https:/www.weforum.org/agenda/2020/03/covid-19-coronavirus-new-yorksimulation-lessons-not-too-late-to-act/

Brunne, V. (2009). Public-private partnerships as a strategy against HIV/AIDS in South Africa: The influence of historical legacies. African Journal of AIDS Research, 8(3), 339-348.

Burke, R., \& Demirag, I. (2017). Risk transfer and stakeholder relationships in public private partnerships. Paper presented at the Accounting Forum.

CBI. (2020). Lessons learnt from China. Retrieved from https://www.cbi.org.uk/articles/covid-19-lesso ns-learnt-from-china/

Chung, D., \& Hensher, D. A. (2018). Public private partnerships in the provision of tolled roads: Shared value creation, trust and control. Transportation Research Part a: Policy and Practice, 118, $341-359$.

CNCDRR. (2020). Foundation disaster relief coordination meeting. Retrieved from https://mp.weixin.qq. $\mathrm{com} / \mathrm{s}$ ?_biz=MzA3MzA5NTc4MA==\&mid=2687798741\&idx=1\&sn=1273dde40ec9c6a942a7 6 ac07a478a31\&chksm=bad462de8da3ebc8428d3f7b2f086e8b3c5aa0487c35d4aa9c682aa8493f 97a640b6050bbb45\&mpshare=1\&scene $=1 \&$ srcid=0312OgZCIDyphWaYJ3FbF3oC\&sharer_share time

Cohen, J., \& Kupferschmidt, K. (2020). China's aggressive measures have slowed the coronavirus. They may not work in other countries [Press release]. Retrieved from https://www.sciencemag.org/news/ 2020/03/china-s-aggressive-measures-have-slowed-coronavirus-they-may-not-work-other-countries

Comendeiro-Maaløe, M., Ridao-López, M., Gorgemans, S., \& Bernal-Delgado, E. (2019). Public-private partnerships in the Spanish National Health System: The reversion of the Alzira model. Health Policy, 123(4), 408-411.

Crisp, L. N. (2008). Global health partnerships: The UK contribution to health in developing countries. Public Policy and Administration, 23(2), 207-213.

De Sousa, A., Mohandas, E., \& Javed, A. (2020). Psychological interventions during COVID-19: Challenges for low and middle income countries. Asian Journal of Psychiatry, 51, 102128.

DXY (2020). COVID-19 Database China. Retrieved from https://ncov.dxy.cn/ncovh5/view/pneumonia

Fang, Y. (2020). Fighting COVID 19: Supportive measures for employees and enterprises in China. Verfassungsblog: On Matters Constitutional. https://doi.org/10.17176/20200322-122751-0

Ferreira, M. S. (2016). Bubble detection in Brazil's stock market: Application of the generalized superior augmented Dickey-Fuller test. Retrieved from http://bibliotecadigital.fgv.br/dspace;/bitstream/handle/10438/16704/FERREIRA\%20M\%20-\%20BUBBLE\%20DETECTION\%20IN\%20BRAZILS\% 20STOCK\%20MARKET_2.pdf

Ferreira, D., \& Marques, R. (2020). Public-private partnerships in health care services: Do they outperform public hospitals regarding quality and access? Evidence from Portugal. Socio-Economic Planning Sciences, 73, 100798.

Givens, A. D., \& Busch, N. E. (2013). Realizing the promise of public-private partnerships in US critical infrastructure protection. International Journal of Critical Infrastructure Protection, 6(1), 39-50.

Gold, J., Hellard, M. E., Lim, M., Dixon, H., Wakefield, M., \& Aitken, C. K. (2012). Public-private partnerships for health promotion: The experiences of the S5 project. American Journal of Health Education, 43(4), 250-253.

Hale, T., Petherick, A., Phillips, T., \& Webster, S. (2020). Variation in government responses to COVID19. Blavatnik School of government working paper, 31 .

Hazra, A., \& Gogtay, N. (2016). Biostatistics series module 6: Correlation and linear regression. Indian Journal of Dermatology, 61(6), 593.

Hubei Provincial People's Government. (2020a). Wuhan communities to keep helping vulnerable. Wuhan: General Office of Hubei Provincial People's Government. Retrieved from http://en.hubei.gov.cn/ news/newslist/202004/t20200408_2207781.shtml

Hubei Provincial People's Government. (2020b). Walmart China to invest 3 billion Yuan in Wuhan. Wuhan: General Office of Hubei Provincial People's Government. Retrieved from http://en.hubei. gov.cn/news/newslist/202004/t20200409_2213540.shtml

Hubei Provincial People's Government. (2020c). Update information on the novel coronavirus in Hubei on April 8, 2020. Wuhan: General Office of Hubei Provincial People's Government. Retrieved from http://en.hubei.gov.cn/news/newslist/202004/t20200409_2212751.shtml

James, L., Shindo, N., Cutter, J., Ma, S., \& Chew, S. K. (2006). Public health measures implemented during the SARS outbreak in Singapore, 2003. Public Health, 120(1), 20-26. 
Karmalkar, S., Klivans, A., \& Kothari, P. (2019). List-decodable linear regression. Paper presented at the Advances in Neural Information Processing Systems.

Lam, P. T., \& Yang, W. (2020). Factors influencing the consideration of Public-Private Partnerships (PPP) for smart city projects: Evidence from Hong Kong. Cities, 99, 102606.

Liu, J., \& Xue, X. (2019). Application of a performance-based public and private partnership model for river management in China: A case study of Nakao River. Journal of Cleaner Production, 236, 117684.

Maraña, P., Labaka, L., \& Sarriegi, J. M. (2020). We need them all: Development of a public private people partnership to support a city resilience building process. Technological Forecasting and Social Change, 154, 119954.

Medhekar, A. (2014). Public-private partnerships for inclusive development: Role of private corporate sector in provision of healthcare services. Procedia-Social and Behavioral Sciences, 157, 33-44.

Nabatchi, T. (2010). Addressing the citizenship and democratic deficits: The potential of deliberative democracy for public administration. The American Review of Public Administration, 40(4), 376-399.

National Health Commission China. (2020). Wuhan's makeshift hospitals close after last patients are discharged [Press release]. Retrieved from http://en.nhc.gov.cn/2020-03/10/c_77596.ht

Odevall, L., Hong, D., Digilio, L., Sahastrabuddhe, S., Mogasale, V., Baik, Y., Choi, S., Kim, J. H., \& Lynch, J. (2018). The Euvichol story-Development and licensure of a safe, effective and affordable oral cholera vaccine through global public private partnerships. Vaccine, 36(45), 6606-6614.

Pagliusi, S., Che, Y., \& Dong, S. (2019). The art of partnerships for vaccines. Vaccine, 37(40), 5909-5919.

Paparoditis, E., \& Politis, D. N. (2018). The asymptotic size and power of the augmented Dickey-Fuller test for a unit root. Econometric Reviews, 37(9), 955-973.

Peeling, R. W., Murtagh, M., \& Olliaro, P. L. (2019). Epidemic preparedness: Why is there a need to accelerate the development of diagnostics? The Lancet Infectious Diseases, 19(5), e172-e178.

Pirkis, J., Livingston, J., Herrman, H., Schweitzer, I., Gill, L., Morley, B., Grigg, M., Tanaghow, A., Yung, A., Trauer, T., Burgess, P., \& Trauer, T. (2004). Improving collaboration between private psychiatrists, the public mental health sector and general practitioners: Evaluation of the Partnership Project. Australian \& New Zealand Journal of Psychiatry, 38(3), 125-134.

Ramenah, H., Casin, P., Ba, M., Benne, M., \& Tanougast, C. (2018). Accurate determination of parameters relationship for photovoltaic power output by augmented dickey fuller test and engle granger method. AIMS Energy, 6(1), 19-48.

Santandrea, M., Bailey, S., \& Giorgino, M. (2016). Value for money in UK healthcare public-private partnerships: A fragility perspective. Public Policy and Administration, 31(3), 260-279.

Schmidt, D., \& Dmytryk, N. (2014). Exploring a public-private partnership new-graduate physiotherapy recruitment program: A qualitative study. Australian Journal of Rural Health, 22(6), 334-339.

Sengyee, L. (2020). How China's industrial internet is fighting COVID-19. Paper presented at the World Economic Forum.

Shibu, V., Daksha, S., Rishabh, C., Sunil, K., Devesh, G., Lal, S., Jyoti, S., Kiran, R., Bhavin, V., Radha, T., \& Amit, K. (2020). Tapping private health sector for public health program? Findings of a novel intervention to tackle TB in Mumbai, India. Indian Journal of Tuberculosis, 67(2), 189-201.

Sinanovic, E., \& Kumaranayake, L. (2010). The motivations for participation in public-private partnerships for the provision of tuberculosis treatment in South Africa. Global Public Health, 5(5), 479-492.

Smith, M. (2020). How China's health code app is used to fight infection. Retrieved from afr.com website: https://www.afr.com/world/asia/how-china-s-health-code-app-is-used-to-fight-infection-20200 424-p54mzk

Smith, K. M., Machalaba, C. C., Seifman, R., Feferholtz, Y., \& Karesh, W. B. (2019). Infectious disease and economics: The case for considering multi-sectoral impacts. One Health, 7, 100080.

Tan, S. (2020). China's novel health tracker: Green on public health, red on data surveillance. Retrieved from https://www.csis.org/blogs/trustee-china-hand/chinas-novel-health-tracker-green-publichealth-red-data-surveillance

Taylor, M. R., Agho, K. E., Stevens, G. J., \& Raphael, B. (2008). Factors influencing psychological distress during a disease epidemic: Data from Australia's first outbreak of equine influenza. BMC Public Health, 8(1), 347. 
Thadani, K. B. (2014). Public private partnership in the health sector: Boon or bane. Procedia-Social and Behavioral Sciences, 157, 307-316.

The State Council of China. (2020). Fighting Covid-19 China in action. Government of PR China.

Tol, W. A., Leku, M. R., Lakin, D. P., Carswell, K., Augustinavicius, J., Adaku, A., Au, T. M., Brown, F. L., Bryant, R. A., \& Garcia-Moreno, C. (2020). Guided self-help to reduce psychological distress in South Sudanese female refugees in Uganda: A cluster randomised trial. The Lancet Global Health, $8(2)$, e254-e263.

Ung, C. O. L. (2020). Community pharmacist in public health emergencies: Quick to action against the coronavirus 2019-nCoV outbreak. Research in Social and Administrative Pharmacy. https://doi.org/ 10.1016/j.sapharm.2020.02.003

Wang, O. (2020). Coronavirus: China backs free trade in masks despite shortages. China Economy. Retrieved from https://www.scmp.com/economy/china-economy/article/3065264/china-backs-freetrade-masks-despite-coronavirus-induced

Wong, E. L., Yeoh, E.-K., Chau, P. Y., Yam, C. H., Cheung, A. W., \& Fung, H. (2015). How shall we examine and learn about public-private partnerships (PPPs) in the health sector? Realist evaluation of PPPs in Hong Kong. Social Science \& Medicine, 147, 261-269.

Woo, R., Sun, Y., Tian, Y. L., Liangping, G., Goh, B., \& Chen, Y. (2020). New coronavirus infections may drop to zero by end-March in Wuhan: Chinese government expert. HEALTHCARE \& PHARMA. Retrieved from Reuters website: https://www.reuters.com/article/us-healthcare-coron avirus-china/new-coronavirus-infections-may-drop-to-zero-by-end-march-in-wuhan-chinese-gover nment-expert-idUSKBN20S02J

World Bank. (2019). PPPLRC (PPP Legal Resource Center). Retrieved from https://ppp.worldbank.org/ public-private-partnership/about-ppplrc-ppp-legal-resource-center

World Economic Forum. (2020). Fourth Industrial Revolution. Retrieved from https://www.weforum.org/ agenda/2021/06/the-private-sector-is-taking-the-lead-on-enabling-digital-inclusion-here-s-how/

Wu, X., Xu, X., \& Wang, X. (2020). 6 lessons from China's Zhejiang Province and Hangzhou on how countries can prevent and rebound from an epidemic like COVID-19. The World Economic Forum COVID Action Platform. Retrieved from weforum.org website: https://www.weforum.org/agenda/ 2020/03/coronavirus-covid-19-hangzhou-zhejiang-government-response/

Xiang, Y.-T., Yang, Y., Li, W., Zhang, L., Zhang, Q., Cheung, T., \& Ng, C. H. (2020). Timely mental health care for the 2019 novel coronavirus outbreak is urgently needed. The Lancet Psychiatry, 7(3), 228-229.

Xiao, Z., \& Lam, J. S. L. (2019). Willingness to take contractual risk in port public-private partnerships under economic volatility: The role of institutional environment in emerging economies. Transport Policy, 81, 106-116.

Xinhua. (2020). Xi Focus: With virus basically curbed, China pushes ahead battle against economic fallout [Press release]. Retrieved from http://www.xinhuanet.com/english/2020-03/12/c_138870411. htm

Xiong, W., Chen, B., Wang, H., \& Zhu, D. (2019). Governing public-private partnerships: A systematic review of case study literature. Australian Journal of Public Administration, 78(1), 95-112.

Xue, Y., Temeljotov-Salaj, A., Engebo, A., \& Lohne, J. (2020). Multi-sector partnerships in the urban development context: A scoping review. Journal of Cleaner Production, 268, 122291.

Yan, A. (2020). Shanghai companies begin production of face masks that can be reused up to 10 times. South China Morning Post (SCMP). Retrieved from https://www.scmp.com/news/china/society/artic le/3052180/shanghai-companies-begin-production-face-masks-can-be-reused-10

Zhang, Y.-C., Luo, W.-Z., Shan, M., Pan, D.-W., \& Mu, W.-J. (2020). Systematic analysis of PPP research in construction journals: from 2009 to 2019. Engineering, Construction and Architectural Management, 27(10), 3309-3339. https://doi.org/10.1108/ECAM-03-2020-0178

Zubașcu, F. (2020). EU puts $€ 45 \mathrm{M}$ into $€ 90 \mathrm{M}$ public-private partnership for coronavirus vaccine research. In total, European Commission has pledged $€ 232 \mathrm{M}$ to help contain coronavirus outbreak, as Italy becomes an infection hotspot. Retrieved from https://sciencebusiness.net/news/eu-putseu45m-eu90m-public-private-partnership-coronavirus-vaccine-research

Zumla, A., Petersen, E., Nyirenda, T., \& Chakaya, J. (2015). Tackling the tuberculosis epidemic in subSaharan Africa-unique opportunities arising from the second European Developing Countries Clinical Trials Partnership (EDCTP) programme 2015-2024. International Journal of Infectious Diseases, 32, 46-49. 
Publisher's Note Springer Nature remains neutral with regard to jurisdictional claims in published maps and institutional affiliations.

Hafiz Syed Mohsin Abbas is a Ph.D. Scholar in the College of Public Administration (CPA) in Huazhong University of Science and Technology, Wuhan, China.

Xiaodong Xu is a Ph.D. Professor and Ph.D. Supervisor. He is Professor in the college of Public Administration, and University Vice President in HUST (Main Campus), Wuhan, Hubei, in P.R. China.

Chunxia Sun is a Ph.D. Associate Professor \& Ph.D. Vice Supervisor. She is an Associate Professor in E-Governance in CPA and had been a Visiting Scholar at State University of Arizona, USA. She is also a faculty at College of Public Administration (CPA) in Huazhong University of Science and Technology, Wuhan, China.

Samreen Gillani is a Research Associate and Independent Research Scholar. She post-graduated from University of Central Punjab (UCP), Lahore, Punjab Pakistan.

Muhammad Ahsan Ali Raza is a Ph.D. Scholar at School of Economics and Management, Beijing University of Posts and Telecommunications, Beijing, PR China.

\section{Authors and Affiliations}

\section{Hafiz Syed Mohsin Abbas ${ }^{1}(\mathbb{1})$ Xiaodong $\mathrm{Xu}^{2} \cdot$ Chunxia Sun $^{2} \cdot$ Samreen Gillani ${ }^{3}$. Muhammad Ahsan Ali Raza ${ }^{4}$}

Xiaodong Xu

xiaodong-xu@hust.edu.cn

Chunxia Sun

chunxia222@126.com

Samreen Gillani

samreengillani5@gmail.com

Muhammad Ahsan Ali Raza

raza.ahsanali@gmail.com

1 College of Public Administration (CPA), Huazhong University of Science and Technology

(HUST) Main Campus, Huahong International Student Apartment, Wuhan, Hubei,

People's Republic of China

2 College of Public Administration (CPA), Huazhong University of Science and Technology (HUST Main Campus), Wuhan, People's Republic of China

3 School of Economics, University of Central Punjab (UCP), Lahore, Punjab, Pakistan

4 School of Economics and Management, Beijing University of Posts and Telecommunications (BUPT), Beijing, People's Republic of China 